\title{
The Effect of a Winter Garden on Energy Consumption of a Detached Passive House
}

\author{
Agata Stolarska ${ }^{1 *}$, Karolina Kurtz-Orecka', Sylwia Mielnikiewicz ${ }^{1}$ \\ ${ }^{1}$ Department of Building Physics and Building Materials, Faculty of Civil Engineering and Architecture, West \\ Pomeranian University of Technology Szczecin, al. Piastów 50, 70-311 Szczecin, Poland \\ * Corresponding author's e-mail: siwinska@zut.edu.pl
}

\begin{abstract}
This paper addresses the effect of a winter garden in a passive detached house on its energy parameters. In order to carry out the study, it was necessary to design a dwelling building compliant with the passive construction standards. The house was designed as a detached two-storey building with a pitched roof and no basement, constructed using traditional brick structure of double-layer walls. The building was intended for construction in north-western Poland, Central Europe, in Pomerania Region. Compliance with the requirements of passive building standards allowed for the use of a buffer zone in the form of a winter garden. Within the project, the garden was designed as an enclosed unconditioned area located at the southern side of the living room. In the winter garden, there are ventilation openings and air inlets intended stay closed during the autumn-winter season. However, in the summer months, they are necessarily opened to provide air circulation. This solution will help to avoid overheating and achieving tropical temperatures inside the garden in the summer. Additionally, there are white venetian blinds used on the garden's vertical outside walls and colourful roof marquise. For the purpose of the study, a winter garden was designed in the form of a $4.36 \mathrm{~m} \times 3.03 \mathrm{~m}$ rectangle with a pent roof and slope inclination of $25^{\circ}$. Its design is based on a mullion and transom facade system. It consists of $50 \mathrm{~mm}$ wide profiles and double-glazed windows. The calculations related to the energy balance were performed for the two adopted variants. The heat gains and losses as well as dynamic parameters and heat demand were evaluated. It was found that the winter garden has no significant influence on the temperature conditions in the building. This applies primarily to a small part of the facade to which it is adjacent. In addition, the effect of the adopted monthly calculation methodology on the obtained parameters was shown. In general, the addition of a winter garden to the building reduced the overall demand for space heating and ventilation in the heated area during the year by more than $30 \%$. In the case of the second variant, the duration of the heating period was also reduced by almost 230 hours. This also resulted in lower annual primary, final and usable energy demand values. Finally, it was demonstrated that a winter garden has a positive effect on the energy balance of a building in climate of north part of Central Europe.
\end{abstract}

Keywords: passive construction, winter garden, solar profits, energy balance

\section{INTRODUCTION}

The efforts to reduce the heat demand in buildings have a very high impact on the energy system. Therefore, designing energy-efficient houses has become an objective for engineers. For this reason the authors decided to analyse the energy parameters of a passive house in two variants, i.e. a standard version as a detached residential building and in a version with a winter garden. These variants enable determining the extent to which the installation of a winter garden reduces the energy demand of a building.

A winter garden can be referred to as conservatory, orangery or glass veranda. Free standing winter gardens can be distinguished as completely separate buildings or as part of a house. Originally, their task was to create an additional living space, which was usually connected with a library or a dining room. This space was supposed to provide an opportunity to protect one from the harsh winter climate while at the same time enabling to 
spend time inside the garden. Orangery, due to its microclimate, also allowed cultivating plants in them [Frantz et al., 2000]. Winter gardens used to be constructed mainly for the aesthetic and entertainment reasons. However, in the 1870s, when the energy crisis occurred, the initial idea of building greenhouses was revisited. The original concept was closely related to the passive use of solar radiation. Emphasis was placed on building the eco-friendly glass houses that use air movement to heat them. Glass extensions were treated as thermal shields [Frantz et al., 2000]. In the present day, a glass veranda is primarily a kind of "solar collector", which extracts and stores heat by means of the greenhouse effect. In addition, it reduces the heat loss in adjacent rooms [Kaczkowska, 2009]. Consequently, the most important tasks of a winter garden are to save energy, increase the living space and ensure a healthy microclimate by the incorporation of plants. It is worth noting that in the 19th century, the structures of unheated household greenhouses allowed them to be kept there only in summer or in the so-called mild season. Because of the increasing technological advances that help avoiding leaks and the constantly improving performance of the glass, winter gardens are used all year round [Frantz et al., 2000]. In this case, the created additional room may serve as a living room, dining room, workplace or a meeting place without any relevance to the time of year [Winter garden $-\mathrm{a}$ living room under glass, 2012].

The most favourable location for a winter garden is on the southern side of the building, which is best illuminated. The orangery can also be planned on the south-east or south-western side [Frantz et al., 2000]. The possibility of locating the winter garden on the northern side is also worth mentioning. However, in this situation, it is not possible to talk about heating the house by means of a winter garden, because only dispersed solar radiation reaches the house. The orangery can only act as a type of heat shield that protects the northern wall of the building from direct cooling at low temperatures and from cold winds.

Particular attention has been paid to the buffer spaces in the study [Chwieduk, 2014]. Different technologies, their glazing and their installation in dependence on climatic conditions have been discussed.

The supporting structures used in winter gardens are usually made of aluminium or wood, and less frequently made of PVC reinforced with steel due to their thermal conductivity. The best parameters are achieved in the case of the aluminium structures with thermal insulation inserts, due to excellent thermal insulation parameters. Moreover, it does not require any maintenance, which is necessary when using wood [Zwolska, 2012]. Moreover, the wooden profiles must have larger cross-sections, which results in a reduction of the glass surface. Many solutions can be found in manufacturers' catalogues, and their profiles are freely shaped, which allows for the creation of complex forms [Frantz et al., 2000]. System constructions are most often used due to the achievement of the appropriate parameters. They provide detailed design details for joints such as the roof and wall joints or rainwater drainage systems [Zwolska, 2012]. The design of a winter garden must also be selected taking into account strength, thermo-humidity and functional-utility parameters. They are mainly influenced by the orientation and architecture of the garden, wind and snow stress zones and the need to ensure resistance to rainwater [Makarewicz, 2007].

The roof of a winter garden should have a slope of at least $20^{\circ}$ in order to avoid condensation of water vapour, facilitate automatic snow sliding and, most importantly, ensure proper ventilation in summer.

The conditions in the winter garden depend primarily on the characteristics of the glazing. The glazing used should meet many requirements, out if which the most important is to ensure thermal insulation. Moreover, it is desirable when they control the solar radiation, protect against noise, dirt and burglary and reduce the condensation of water vapour. The most common types of glazing are the insulating glass units consisting of three glass panes filled with argon. In addition, reflective coatings can be used to reduce the orangery exposure to solar radiation [Zwolska, 2012]. These effects can be applied on the roof to reduce the amount of sunlight entering the building during the summer period. Furthermore, the roof glazing in the winter garden should be made of safety glass to protect the occupants in the event of an accident.

During the summer, awnings, roller blinds or external blinds are used in order to avoid excessive sunlight. Another way to reduce the radiation is to employ natural solutions in the form of deciduous trees or climbing plants. A ventilation system is also required in the winter garden to avoid achieving tropical temperatures. It is also 
recommended to separate the glass veranda from the rest of the house with a thermal barrier, e.g. a 30-36 cm thick brick wall [Frantz et al., 2000]. When the orangery is separated from the rest of the house, it is possible control the temperature inside the building using ventilation. By supplying the warm air from the greenhouse into the building on cold days, one can heat the house or by extracting air from the outside it is possible to cool the greenhouse when it is too hot [Galloway, 2007]. Similarly, the ventilators discharge the heated air outside the winter garden and reduce the humidity in the greenhouse. Their surface area should be about $10-16 \%$ of the glazing. It is also possible to use automatic air conditioning, which is equipped with solar sensors connected with ventilators and the elements protecting the winter garden. In this case, the system itself controls the temperature and humidity and it is up to the system to decide when to extend the blinds or open the window.

The floor in the winter garden should be made of the materials resistant to temperature changes and humidity. It is also recommended to use a dark floor, with the advantage that it absorbs much more heat, which can be released later.

\section{ASSUMPTIONS}

It was assumed that the designed building would be constructed in a passive standard and would be intended for a family of four. The house is designed as a detached single-family two-storey building with a gable roof with a slope angle of $40^{\circ}$ and no basement. The building was to be built in a traditional masonry construction with two layers of walls. The body of the building was to be simple in order achieve the best possible passive parameters. The building was designed to be built under climatic conditions similar to those prevailing in the city of Szczecin.

The load-bearing walls are designed as double-layered, made of $40 \mathrm{~cm}$ thick cellular concrete blocks with thin layer mortar. The insulation layer was to be made of mineral wool with a thickness of $20 \mathrm{~cm}$. The project envisaged a gable roof with a slope inclination of $40^{\circ}$. The roof insulation was made of mineral wool $18 \mathrm{~cm}$ thick, laid between rafters and pliers and an additional layer of $15 \mathrm{~cm}$ inserted under rafters and pliers from the inside. Typical external doors with the coefficient of thermal transmittance, $U_{D}$, equal to $0.73 \mathrm{Wm}^{-2} \mathrm{~K}^{-1}$ were adopted. On the ground floor and in the attic, double-chamber aluminium windows with the coefficient of thermal transmittance for the whole window, $U_{w}$, equal to $0.8 \mathrm{Wm}^{-2} \mathrm{~K}^{-1}$ were adopted. On the other hand, the wooden, pivot windows with the coefficient of thermal transmittance for the whole window $U_{w}$ equal to $0.58 \mathrm{Wm}^{-2} \mathrm{~K}^{-1}$ were used on the roof. Inside the building, the use of mechanical ventilation, supply and exhaust ventilation with heat recovery was envisaged. The calculation included a recuperator with an efficiency of $90 \%$. In the designed building, an air-water pump was used to warm and heat domestic hot water. Moreover, the house has a water tank and underfloor heating. No cooling installation was planned in the analysed building.

On the other hand, the winter garden was designed as a closed zone with no air-conditioning, located on the south side next to the living room. It was to be added to the building without the possibility of going outside and connected to the house by a large $2.2 \times 2.2 \mathrm{~m}$ window and a $2.2 \times 0.90 \mathrm{~m}$ window, with the function of an entrance door to the garden. It was assumed that the winter garden would be used mainly in summer, and during winter it would be closed and not used by household members, so as not to cool down the rest of the house. In this way, it will act as a heat shield for a part of the building.

Ventilation holes and ventilators were provided in the winter garden, which was also to be closed in the autumn, i.e. the winter season. In turn, during the summer periods, they have to be opened in order to ensure the circulation of air. This solution ensured that overheating and tropical temperatures inside the garden are avoided. White Venetian blinds used on the outside of the garden on vertical walls and a colourful awning on the roof will also support this goal. A winter garden was designed on a rectangular projection with external dimensions of $4.36 \times 3.025 \mathrm{~m}$ with a single-pitched roof and a $25^{\circ}$ slope inclination. Its design is based on a post and beam system. It consists of aluminium profiles with a width of $50 \mathrm{~mm}$, double glazed units with a solar radiation transmittance coefficient, $g$, equal to 0.5 and a warm inter-pane glass frame. Figures 1 and 2 show a projection of the ground floor and attic of the designed building with the winter garden. 


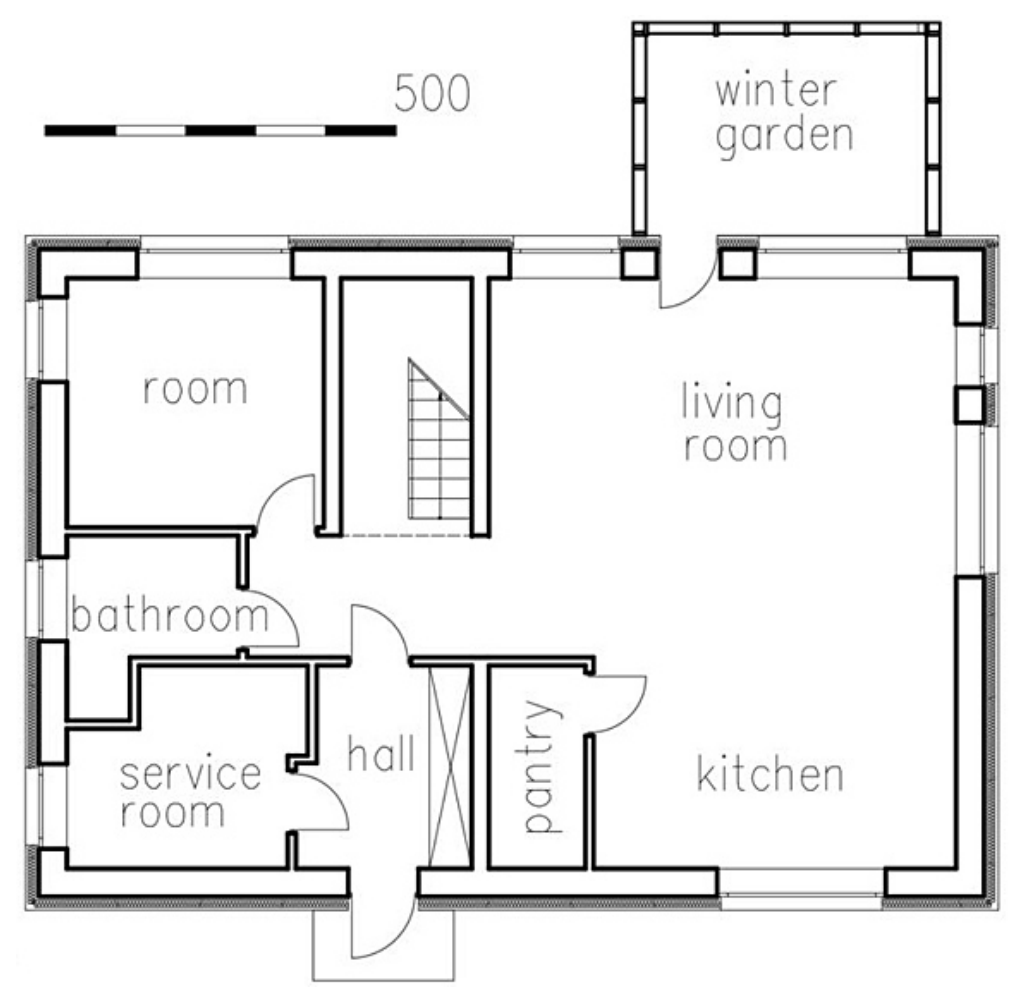

Fig. 1. Ground floor projection, based on (Mielnikiewicz, 2018)

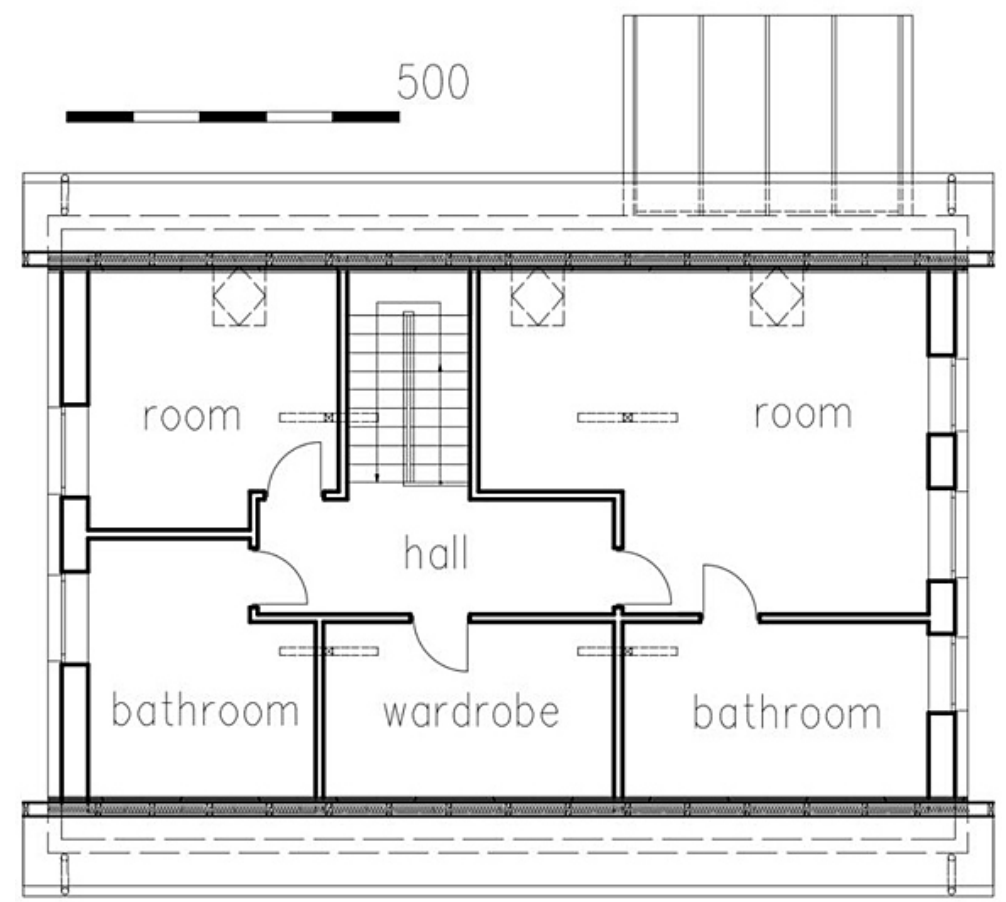

Fig. 2. The attic projection, based on (Mielnikiewicz, 2018)

\section{TESTING METHODOLOGY AND RESULTS}

Variant energy balance of energy demand for space heating and ventilation was carried out with the method of monthly balances. The demand for usable, final and primary energy was determined.
The calculations of the demand for non-renewable primary energy were carried out in accordance with the methodology presented in [Rozporządzeniem Ministra Infrastruktury i Rozwoju z dnia 27 lutego 2015 r. w sprawie metodologii wyznaczania charakterystyki energetycznej budynku 
lub części budynku oraz świadectw charakterystyki energetycznej, 2019]. The necessary climatic data were adopted for the Szczecin-Dąbie reference meteorological station according to [Data for energy calculations of buildings, 2019]. First of all, the calculations related to the energy balance of the building for the variant without the winter garden were performed. Then the calculations were repeated, placing the winter garden in accordance with the accepted assumptions for the project. In the second calculation variant, the buffer zone of the winter garden was taken into account as an unconditioned space with a variable resulting temperature, which was determined in the annual course on the basis of [PN-EN ISO 13789:2008].

The initial analysis showed that both designed building variants meet all the assessment criteria for a passive house standard. Tables 1 and 2 show a summary of the results achieved for the designed building together with the requirements for passive construction (PH standard).

Subsequently, the values of heat gains received were compared. The created graphs (Fig. 3 and Fig. 4) present the calculation values of solar gains, and total gains in each month for two variants. It should be reminded here that at the calculation stage it was assumed that the solar gain values of the winter garden in option II were fully used to raise the temperature in the orangery. Therefore, it was not added to solar gains. The solar gains from window surfaces in the wall

Table 1. Comparison of the designed building in two variants with the passive house standard [Mielnikiewicz, 2018]

\begin{tabular}{|c|c|c|c|}
\hline \multirow{2}{*}{ Factors } & \multicolumn{2}{|c|}{ Designed building } & \multirow{2}{*}{ PH standard } \\
\cline { 2 - 3 } & Variant I & Variant II & \\
\hline$E U\left[\mathrm{kWh} \mathrm{m}^{-2} \mathrm{a}^{-1}\right]$ & 2.54 & 1.76 & $\leq 15$ \\
\hline$E P\left[\mathrm{kWh} \mathrm{m}^{-2} \mathrm{a}^{-1}\right]$ & 58.25 & 57.28 & $\leq 120$ \\
\hline
\end{tabular}

section between the orangery and the building interior were also excluded. As it can be seen from the graphs below, the effect of this measure is that lower solar gains were obtained for Option II. The area of the glazing taken into account in the calculations was reduced in order to increase the temperature inside the winter garden. On the other hand, monthly internal gains remained unchanged. The nature of both charts is very similar, which is due to the fact that in the end only solar gains influenced the variation in total heat gains.

Figures 5 and 6 illustrate the heat loss by permeability and ventilation for both variants. It should be noted that in the calculations of variant II for the part of the wall in contact with the orangery, negative values were obtained for the months from typical March to typical November. This is due to the very high temperatures obtained in the winter garden, which exceed the temperature inside the building. In fact, such high temperatures will not be achieved because the ventilation openings and ventilators will be opened in summer. Therefore, the negative values were not taken into account.

The obtained results of heat loss through ventilation are the same for both variants. The winter garden was designed as a separate unconditioned space which is not openly connected to the rest of the house. Therefore, it was not added to the cubic capacity of the building and had no impact on the amount of heat loss through ventilation. On the other hand, the following graphs show the differences in the magnitude of losses by permeability. The losses are smaller for variant II, which clearly indicates that the winter garden fulfils its role as a heat buffer zone of the building. This confirms one of the objectives of winter garden use discussed in the literature [Figiel, 2018]. However, the differences between the variants are not very large, which can be caused by the small size of the garden, which directly covers

Table 2. Comparison of the designed building with the requirements of the PH standard (Mielnikiewicz, 2018)

\begin{tabular}{|l|c|c|}
\hline \multicolumn{1}{|c|}{ Parametr } & PH Standard & Obtained values \\
\hline$U_{\text {max }}\left[\mathrm{Wm}^{-2} \mathrm{~K}^{-1}\right]$ External walls & $\leq 0.15$ & 0.10 \\
\hline$U_{\text {max },}\left[\mathrm{Wm}^{-2} \mathrm{~K}^{-1}\right]$ Roof, ceiling under unheated attics & $\leq 0.15$ & 0.11 \\
\hline$U_{\text {max }}\left[\mathrm{Wm}^{-2} \mathrm{~K}^{-1}\right]$ Ground floor & $\leq 0.15$ & 0.08 \\
\hline$U_{\text {max }}\left[\mathrm{Wm}^{-2} \mathrm{~K}^{-1}\right]$ Windows & $\leq 0.80$ & 0.80 \\
\hline$U_{\text {max }}\left[\mathrm{Wm}^{-2} \mathrm{~K}^{-1}\right]$ Sky lights & $\leq 0.80$ & 0.58 \\
\hline$U_{\text {max }}\left[\mathrm{Wm}^{-2} \mathrm{~K}^{-1}\right]$ External door & $\leq 1.10$ & 0.73 \\
\hline Air tightness of envelope, $n_{50}\left[\mathrm{~h}^{-1}\right]$ & $\leq 0.60$ & 0.60 \\
\hline Heat recovery efficiency & $\geq 75 \%$ & $90 \%$ \\
\hline
\end{tabular}




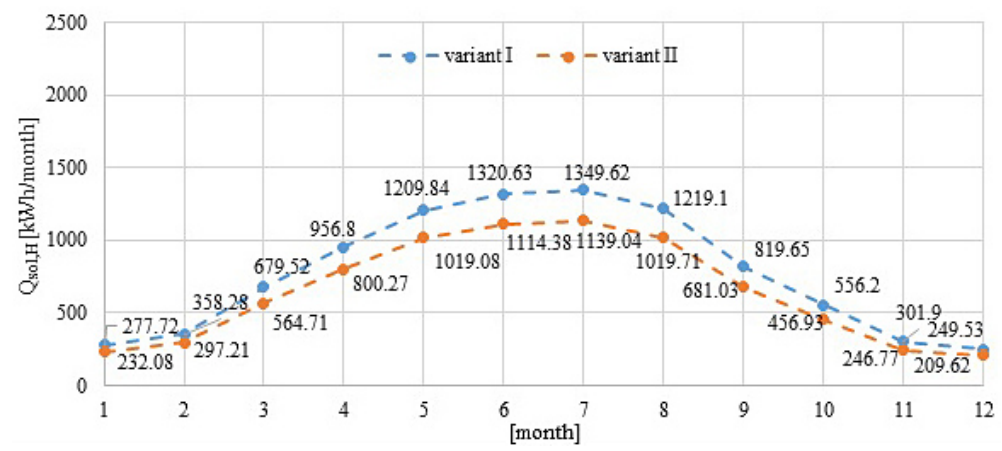

Fig. 3. Summary of gains from solar radiation $Q_{\text {sol, }}$ for individual months [Mielnikiewicz, 2018]

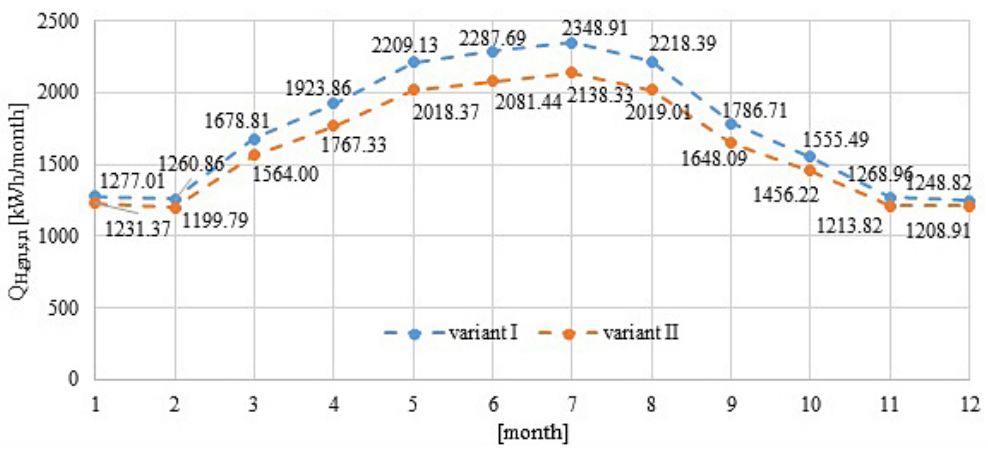

Fig. 4. Summary of total heat gains $Q_{H, g n, s, n}$ for individual months [Mielnikiewicz, 2018]

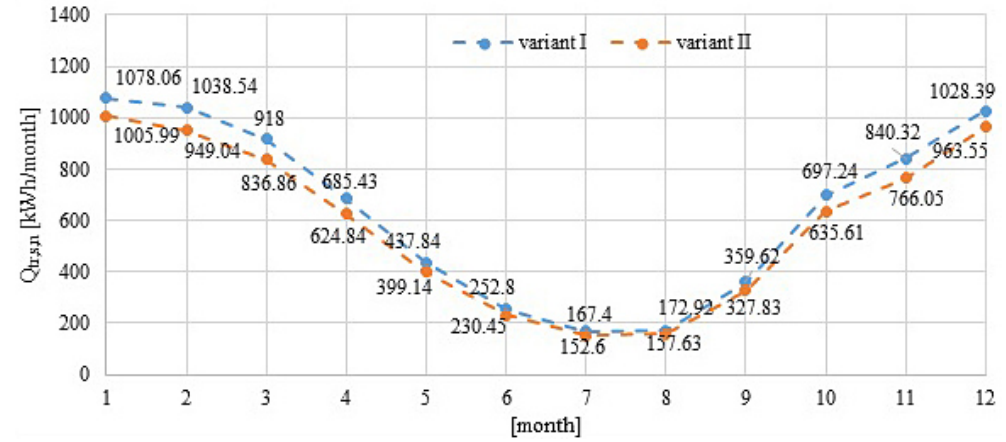

Fig. 5. Summary of monthly heat loss through permeability $Q_{t: s, n}$ for two variants [Mielnikiewicz, 2018]

only about $16 \mathrm{~m}^{2}$ of the southern wall. Moreover, the graphs presented are similar in character, as in the case of solar gains. This situation is caused by the fact that the same components are obtained from the ventilation for two variants. Therefore, the monthly heat losses are differentiated only by heat loss through permeability.

Further differences in calculation concern the dynamic parameters. In the first variant, the values of time constant $\tau$, the numerical parameter in utilization factor $a_{H}$, or the heat transfer coefficient through transmission $H_{t r a d j}$ are constant, while in the II variant they change. The reason for this is the changing temperature in the garden over a period of 12 months, as shown in the graph (Fig. 7).
Due to the adoption of a monthly calculation methodology and the adoption of a tight, unconditioned structure, a very high temperature was obtained inside the winter garden. This, in turn, translated into obtaining the negative values of the coefficient of temperature reduction, $b_{u}$, in the II variant. Therefore, it was decided that only those values of the heat transfer coefficient through transmission $H_{t r i u}$, multiplied by the coefficient $b_{u}$ factor for which $b_{u}>0$, will be added to the calculation of $H_{t ; a d j}$ coefficient. Taking into account the negative values of the $b_{u}$ factor in the calculations would result in unrealistic results. This calculation process would consequently lead to a negative annual energy demand for space heating 


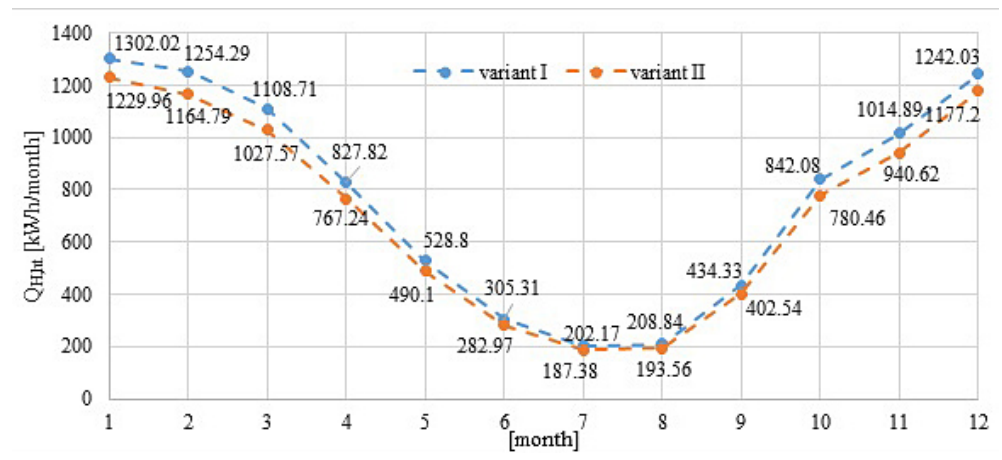

Fig. 6. Summary of monthly heat loss through permeability and ventilation $Q_{H, h t}$ for two variants [Mielnikiewicz, 2018]

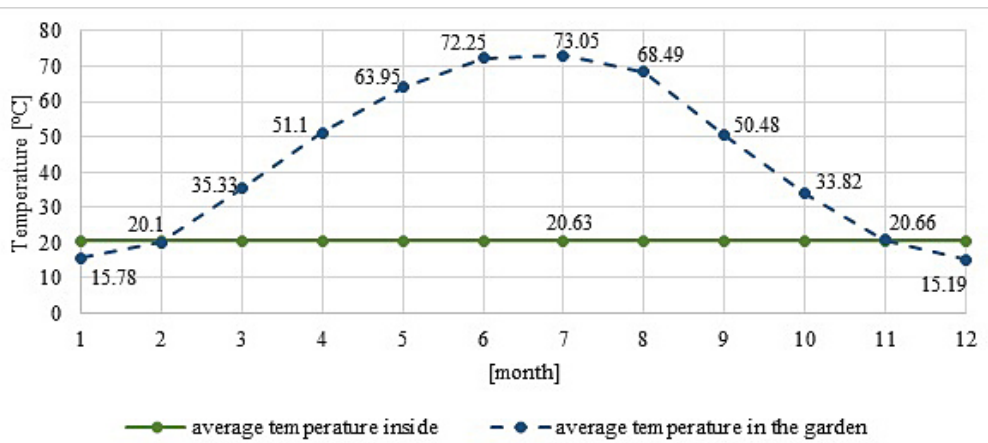

Fig. 7. Graph of winter garden temperatures and indoor temperatures [Mielnikiewicz, 2018]

and ventilation. It was clearly concluded that this calculation would be erroneous because adding a winter garden to a building would not heat the entire house space to such an extent. Realistically, it can only affect the room to which it is attached. The validity of the conclusions reached is confirmed by [Figiel, 2018], in which it was stated that the orangery has no significant influence on the thermal conditions of the whole building. It concerns in particular a small part of the façade to which it is adjacent. In addition, it has already been established that under real conditions in the winter garden, such high temperatures will not be reached in the summer. By opening the ventilation openings and ventilators, the air will circulate in the orangery, preventing it from reaching the tropical temperature levels. Another inaccuracy in the calculations is due to the adoption of the monthly step of the calculations. It does not take into account the variation in temperature during the 24hour period. It is important to remember that the solar gains can only be during the day. During the night, the winter garden will be cooling down. In order to determine the actual temperatures in the winter garden, it is suggested to conduct dynamic calculations with hourly or shorter time step, which would allow establishing a reference to the actual situation in the winter garden. Due to the fact that the activities in question are to a large extent outside the scope of this study, they have not been carried out. The decision to add only the values of the $H_{t r i u}$ heat transfer coefficient to the $H_{t r a d j}$ coefficient, for which the $b_{u}$ temperature reduction coefficient is positive, resulted in positive values of the remaining dynamic parameters. This data enables to estimate the result of the annual energy demand for space heating and ventilation for the II variant, which was presented in the further study, with sufficient accuracy.

In Table 3, a summary of the other most important results obtained during the calculations is presented. Thus, the two designed variants can be directly compared.

While analysing the data listed in Table 3 it can be seen that the same heated area of the building was finally considered in two variants. The winter garden is a separate unconditioned space, which does not affect the size of the heated area. Therefore, also the coefficient of thermal transmittance through ventilation from the heated zone, $H_{v e . s}$ was identical in both variants, since the same building volume was taken into 
Table 3. Summary of the key results for the two variants [Mielnikiewicz, 2018]

\begin{tabular}{|c|c|c|c|}
\hline Symbol & Unit & Variant I & Variant II \\
\hline$A_{f}$ & $\mathrm{~m}^{2}$ & 197.52 & 197.52 \\
\hline$H_{t, i e}$ & $\mathrm{~W} \mathrm{~K}^{-1}$ & 63.91 & 57.36 \\
\hline$H_{t, r i u e}$ & $\mathrm{~W} \mathrm{~K}^{-1}$ & 5.28 & 5.28 \\
\hline$H_{t r i g}$ & $\mathrm{~W} \mathrm{~K}^{-1}$ & 4.99 & 4.99 \\
\hline$H_{t, s}$ & $\mathrm{~W} \mathrm{~K}^{-1}$ & 74.18 & 67.63 \\
\hline$H_{\text {Tiu }}$ & $\mathrm{W} \mathrm{K}^{-1}$ & - & 6.43 \\
\hline$H_{\text {Tue }}$ & $\mathrm{W} \mathrm{K}^{-1}$ & - & 34.80 \\
\hline$H_{v e, s}$ & $\mathrm{~W} \mathrm{~K}^{-1}$ & 15.41 & 15.41 \\
\hline$L_{h}$ & $\mathrm{~h}$ & 1992 & 1764 \\
\hline$Q_{H, n d, n}$ & $\mathrm{kWh} \mathrm{a}^{-1}$ & 502.06 & 346.82 \\
\hline$Q_{k, H}$ & $\mathrm{kWh} \mathrm{a}^{-1}$ & 206.18 & 142.43 \\
\hline$Q_{k, W}$ & $\mathrm{kWh} \mathrm{a}^{-1}$ & 2691.02 & 2691.02 \\
\hline$Q_{p}$ & $\mathrm{kWh} \mathrm{a}^{-1}$ & 11504.77 & 11313.51 \\
\hline$Q_{k}$ & $\mathrm{kWh} \mathrm{a}^{-1}$ & 3834.92 & 3771.17 \\
\hline$Q_{u}$ & $\mathrm{kWh} \mathrm{a}^{-1}$ & 5259.78 & 5104.54 \\
\hline$E_{e, p o m}$ & $\mathrm{kWh} \mathrm{a}^{-1}$ & 937.73 & 937.73 \\
\hline$E P$ & $\mathrm{kWh} \mathrm{m}^{-2} \mathrm{a}^{-1}$ & 58.25 & 57.28 \\
\hline$E K$ & $\mathrm{kWh} \mathrm{m}^{-2} \mathrm{a}^{-1}$ & 19.42 & 19.09 \\
\hline$E U_{1}$ & $\mathrm{kWh} \mathrm{m}^{-2} \mathrm{a}^{-1}$ & 2.54 & 1.76 \\
\hline$E U_{2}$ & $\mathrm{kWh} \mathrm{m}^{-2} \mathrm{a}^{-1}$ & 26.63 & 25.84 \\
\hline & & & \\
\hline
\end{tabular}

account. According to [PN-EN ISO 13789:2008, Thermal performance of buildings - Transmission and ventilation heat transfer coefficients Calculation method] the air conditioned space does not influence the increase of the thermal transmittance coefficient from the heated zone to the ground, $H_{t^{\prime} i g}$. The calculations were performed as if the space did not exist, resulting in obtaining the same results again. No variants were differentiated in terms of installation equipment and demand for usable warm water. Thus, the same values of annual energy demand were obtained for auxiliary energy demand $E_{\text {el,pom }}$ and final energy demand for domestic hot water preparation $Q_{k, W^{*}}$ Considering the differences, it should be noted that variant I was considered as a whole building. In turn, in variant II, the part of the wall that contacts the winter garden and the remaining part of the building was separated for the purposes of calculations. This procedure was necessary, because the heat transfer coefficients from the heated to the unconditioned zone, i.e. $H_{i u}$ and from the unconditioned space to the external environment $-H_{u e}$ are calculated in a different way. This action resulted in different values of thermal transmittance coefficients by permeability. However, they cannot be directly compared, as they apply to other surfaces. On their basis, it is possible to determine the heat losses by permeability and compare their values, which is shown in Figs. 5 and 6.

Turning to the most important final results, it can be see that adding a winter garden to a building reduced the total heat demand for heating and ventilation in a heated zone by more than $30 \%$ over the year. It also reduced the length of the heating period by almost $230 \mathrm{~h}$. The reduction in energy demand for space heating has the consequence of reducing the annual final energy requirement of the building for the heating system, the final energy of the building for the technical systems, the non-renewable primary energy for the technical systems and the utility energy.

These factors, in turn, have a direct impact on the decrease in the annual energy demand indicators EP, EK and EU. Finally, it was shown that the winter garden has a positive effect on the energy balance of the building.

\section{CONCLUSIONS}

For the purpose of this article, a project of a single-family building was created in two variants, in a basic version and expanded with a winter garden. In both variants, the passive house standard was achieved. At the same time, the building was also adjusted to the requirements set by the Polish technical conditions for buildings [Rozporządzeniem Ministra Infrastruktury i Budownictwa z dnia 14 listopada 2017 r. zmieniające rozporządzenie w sprawie warunków technicznych, jakim powinny odpowiadać budynki i ich usytuowanie poz. 2285], in force since December 31, 2020.

From the analysis of the results, the positive effects of the use of the orangery on the energy balance of the heating and ventilation needs of the building were identified. The high solar gains, which are assumed to translate entirely into the heating of a winter garden, significantly increase the temperature in the winter garden. In this way, it creates the buffer zone for the surface to which it adheres, and consequently reduces the heat loss in a given section. It also contributes to the reduction of annual energy demand for space heating and ventilation, which results in a reduction of the final $E P, E K, E U$ indicators. However, it should be remembered that the calculations for variant II showed that the use of the adopted methods introduces inaccuracies in the results obtained. From typical March to 
typical November, higher temperatures were obtained in the winter garden than inside the building. This is due to the assumption that the orangery used for calculations was carried out as a sealed unconditioned space. Another reason is the use of the simplified monthly method for the energy balance, the time step of which is too large and too imprecise. It does not differentiate between the temperature changes in a 24-hour cycle. The inconsistencies in the calculation require further calculation and analysis, a more detailed hourly method or a shorter time step. Many assumptions were made for the purpose of this study, which allowed obtaining real results. They concerned mainly the summation of only the positive losses. The negative values of losses were due to the high temperatures in the garden, which, as mentioned above, will not be achieved in summer due to the opening of ventilation outlets. Furthermore, when calculating the dynamic parameters, it was decided not to take into account the negative values of the temperature reduction coefficient $b_{u}$, because it would have caused unrealistic results, which was explained during the analysis of the results. It was finally concluded that the winter garden, by creating the buffer zone of the building has a positive impact on its energy balance.

\section{REFERENCES}

1. Chwieduk, D., 2014. Chapter 5 - Passive Utilization of Solar Energy in a Building, in: Chwieduk, D. (Ed.), Solar Energy in Buildings. Academic Press, Oxford, 133-171, https://doi.org/10.1016/ B978-0-12-410514-0.00005-0.

2. Data for energy calculations of buildings. Ministerstwo Inwestycji i Rozwoju. http://web/ inwestycje-rozwoj/dane-do-obliczen-energetycznych-budynkow (accessed 7.2.2019).

3. Figiel, E., 2018. Unheated winter gardens and energy saving. Instal 4, 30-33.

4. Frantz, J., Hanke, S., Krampen, M., Schempp, D., 2000. A winter garden closer to nature: examples of architectural designs and plant placement. Wydawnictwo Arkady, Warszawa.

5. Galloway, T., 2007. Solar House: A Guide for the Solar Designer. Elsevier, Oxford: Architectural Press, Amsterdam.

6. Kaczkowska, A., 2009. Passive house. KaBe, Krosno.

7. Makarewicz, M., 2007. Porches, orangeries, winter gardens - the same problems. Świat szkła: okna, drzwi, fasady 10, 18-20.

8. Mielnikiewicz, S., 2018. Design of a single-family house meeting the passive house standard requirements with winter garden. Szczecin.

9. PN-EN ISO 13789:2008, Thermal performance of buildings - Transmission and ventilation heat transfer coefficients - Calculation method.

10. Rozporządzeniem Ministra Infrastruktury i Budownictwa z dnia 14 listopada 2017 r. zmieniające rozporządzenie w sprawie warunków technicznych, jakim powinny odpowiadać budynki i ich usytuowanie, poz. 2285.

11. Rozporządzeniem Ministra Infrastruktury i Rozwoju z dnia 27 lutego 2015 r. w sprawie metodologii wyznaczania charakterystyki energetycznej budynku lub części budynku oraz świadectw charakterystyki energetycznej.

12. Winter garden - a living room under glass, 2012. Świat szkła: okna, drzwi, fasady, 11(168), listopad 2012, 24-25, http:/www.swiat-szkla.pl/component/ content/article/234-wydanie-112012/6855-ogrodzimowy-salon-pod-szkem (accessed 6.28.2019).

13. Zwolska, K., 2012. Winter orangeries. Świat szkła: okna, drzwi, fasady 11, 26. 